\title{
PENGEMBANGAN MEDIA PEMBELAJARAN INTERAKTIF BERBASIS LECTORA INSPIRE PADA MATERI JURNAL PENYESUAIAN UNTUK SISWA KELAS X AKUNTANSI DAN KEUANGAN LEMBAGA SMK NEGERI 1 TEMPEL TAHUN AJARAN 2018/2019
}

\author{
DEVELOPMENT OF INTERACTIVE LEARNING MEDIA BASED ON LECTORA \\ INSPIRE IN ADJUSTMENT JOURNAL MATERIALS FOR STUDENTS IN CLASS $X$ \\ ACCOUNTING AND FINANCIAL INSTITUTIONS SMK N 1 TEMPEL ACADEMIC \\ YEAR 2018/2109
}

Oleh:

Anis Mahmudah

Prodi Pendidikan Akuntansi Universitas Negeri Yogyakarta mahmudah617@gmail.com

Adeng Pustikaningsih

Staf Pengajar Jurusan Pendidikan Akuntansi Universitas Negeri Yogyakarta

\begin{abstract}
Abstrak
Penelitian ini bertujuan untuk: (1) mengembangkan Media Pembelajaran Interaktif Berbasis Lectora Inspire pada materi Jurnal Penyesuaian untuk Siswa Kelas X Akuntansi dan Keuangan Lembaga SMK Negeri 1 Tempel; (2) mengetahui kelayakan media pembelajaran interaktif berbasis Lectora Inspire berdasarkan validasi/penilaian dari ahli materi, ahli media dan praktisi pembelajaran; (3) mengetahui penilaian siswa terhadap media pembelajaran interaktif berbasis Lectora Inspire. Jenis penelitian dan pengembangan (Research and Development) ini menggunakan model pengembangan ADDIE hanya sampai tahap keempat yaitu Implementation. Pada tahap Development, media pembelajaran interaktif berbasis Lectora Inspire dinilai kelayakannya oleh 1 ahli materi (Dosen Pendidikan Akuntansi FE UNY), 1 ahli media (Dosen Pendidikan Akuntansi FE UNY) dan 1 praktisi pembelajaran (guru akuntansi SMK Negeri 1 Tempel). Tahap implementasi melalui dua tahapan yaitu uji coba kelompok kecil (9 siswa) dan Uji Coba Lapangan (30 siswa). Hasil penelitian menunjukkan bahwa (1) Media Pembelajaran Berbasis Lectora Inspire dikembangkan melalui lima tahapan yaitu (a) Analisis (Analysis), b) Desain (Design), c) Pengembangan (Development) d) Impelementasi (Implementation) dan e) Evaluasi (Evaluation); (2) tingkat kelayakan media pembelajaran interaktif berbasis Lectora Inspire berdasarkan penilaian ahli materi diperoleh rata-rata 4,53 yang termasuk dalam kategori sangat layak, ahli media diperoleh rata-rata 4,48 yang termasuk dalam kategori sangat layak, dan praktisi pembelajaran diperoleh rata-rata 4,60 yang termasuk dalam kategori sangat layak; (3) Penilaian siswa kelas X Akuntansi dan Keuangan Lembaga 1 SMK Negeri 1 Tempel diperoleh rata-rata skor keseluruhan 4,24 yang termasuk dalam kategori sangat layak. Berdasarkan hasil penelitian tersebut, media pembelajaran interaktif berbasis Lectora Inspire yang dikembangkan ini sangat layak digunakan sebagai media pembelajaran akuntansi.
\end{abstract}

Kata kunci: Media Pembelajaran Interaktif, Lectora Inspire, ADDIE

\section{Abstract}

This research aims to: (1) develop Interactive Learning Media Based on Lectora Inspire in the material of Adjusting Journal for Class X of Accounting and Finance Institution SMK Negeri 1 
Tempel; (2) determine the feasibility of Lectora Inspire-based interactive learning media based on validation lassessment from material experts, media experts and accounting learning practitioners; (3) determine the assessment of students to interactive learning media based on Lectora Inspire. Research and development with the ADDIE development model. In the Development stage, Lectora Inspire-based interactive learning media was assessed for its feasibility by 1 material expert (Lecturer of Accounting Education FE UNY), 1 media expert (Lecturer of Accounting Education FE UNY) and 1 accounting learning practitioner (SMK Negeri 1 Tempel accounting teacher). The implementation phase through two stages, namely small group trials (9 students) and field research (30 students). The results showed that (1) Lectora Inspire Based Learning Media was developed through four stages, they were (a) Analysis, b) Design, c) Development and d) Implementation, e) Evaluation; (2) the level of feasibility of Lectora Inspire-based interactive learning media based on the assessment of material experts gave 4.53 average score wihich is included very feasible category, media experts gave 4.48 average score which is included very feasible category, and accounting learning practitioners gave 4.60 average score which is included in the very feasible category; (3) Assessment of class $X$ Accounting and Finance Institutions 1 SMK Negeri 1 Tempel gave 4.24 average score which is included very feasible category. Based on the results of these research, interactive learning media based on Lectora Inspire developed was very feasible to use as for accounting learning media.

Keywords: Interactive Learning Media, Lectora Inspire, ADDIE

\section{PENDAHULUAN}

Revolusi industri 4.0 yang digagas oleh Profesor Klaus Schawb menjadi tantangan bagi semua kalangan. Berbagai lembaga dan industri mengalami disruptif teknologi yang begitu cepat. Perkembangan teknologi informasi dan ilmu pengetahuan memiliki pengaruh yang besar dalam berbagai bidang kehidupan manusia, salah satunya yaitu dibidang pendidikan. Peningkatan mutu pendidikan dikatakan berhasil jika kualitas pendidikan yang telah ditetapkan dapat tercapai dan berdampak pada meningkatnya kualitas sumber daya manusia. Tidak terkecuali, pendidikan di Sekolah Menengah Kejuruan (SMK) yang harus terus meningkatkan kemampuan daya saing sumber daya manusia. Pendidikan di era 4.0 harus bisa memanfaatkan teknologi dalam proses pembelajaran. Hal ini bisa memberikan solusi bahwa pembelajaran dapat dilakukan secara continue. Guru sebagai tiang utama dalam pendidikan harus bisa mengikuti era industri 4.0 dengan cara memperdalam kompetensi. Pernyataan Jack Ma (CEO Alibaba Group) dalam World Economic Forum 2018 menyatakan bahwa pendidikan pada abad ini mempunyai tantangan besar (liputan6.com). Jika guru tidak bisa mengikuti perkembangan dan tidak mengubah cara mendidik dan belajar mengajar, maka 30 tahun mendatang akan mengalami kesulitan. Guru era 4.0 harus memiliki kompetensi tentang teknologi informasi. Teknologi dapat membantu guru untuk mengelola materi lebih efisien dan fokus sehingga proses pembelajaran dapat berjalan efektif. Proses pembelajaran berlangsung karena adanya interaksi antara guru dan peserta didik. Interaksi antara keduanya akan dipengaruhi oleh berbagai hal diantaranya pemahaman peserta didik, bahan pembelajaran, sumber belajar, media pembelajaran dan fasilitas yang tersedia di lembaga sekolah. Guru memiliki peranan penting dalam keberhasilan proses pembelajaran. Namun, pembelajaran yang dilaksanakan di Indonesia ternyata masih ada beberapa masalah. "Permasalahan pembelajaran di Indonesia terjadi karena beberapa faktor yaitu pendekatan dalam 
pembelajaran, faktor perubahan kurikulum dan faktor kompetensi guru" (Afifah N, 2015:43). Guru masih 60\% terfokus menggunakan pendekatan pembelajaran konvensional. Perubahan kurikulum yang diterapkan di Indonesia membuat guru dituntut bisa mengikuti setiap kurikulum yang berlaku. Dalam era industri 4.0, peningkatan kompetensi guru diperlukan.

Media pembelajaran merupakan alat bantu yang mempermudah penyampaian pesan pembelajaran dari guru kepada peserta didik. Nana Sudjana dan Ahmad Rivai (2017: 1) mengartikan "media pembelajaran adalah sebuah alat bantu mengajar yang ada dalam komponen metodologi sebagai salah satu lingkungan belajar yang diatur oleh guru". Pengertian tersebut sejalan dengan yang diungkapkan oleh Suryani dkk (2018: 5) "media pembelajaran adalah segala bentuk dan sarana penyampaian informasi yang dibuat atau dipergunakan sesuai dengan teori pembelajaran, dapat digunakan untuk tujuan pembelajaran dalam menyalurkan pesan, merangsang pikiran, perasaan, perhatian, dan kemauan siswa sehingga dapat mendorong terjadinya proses belajar yang disengaja, bertujuan, dan terkendali”. Berdasarkan pendapat ahli tersebut, maka dapat disimpulkan bahwa bentuk komunikasi tidak akan berjalan tanpa bantuan sarana untuk menyampaikan pesan. Bentuk-bentuk stimulus dapat dipergunakan sebagai media, diantaranya adalah hubungan atau interaksi manusia, realitas, gambar atau tidak, tulisan, dan suara direkam. Dengan kelima bentuk stimulus ini, akan membantu siswa mempelajari bahan pelajaran. Penggunaan media pembelajaran yang efektif akan membantu menumbuhkan motivasi dan mengatasi kesulitan belajar siswa. Hal ini diungkapkan dalam penelitian yang telah dilakukan oleh Kartika Bunga N.N (2018: 8) yang menyatakan bahwa penggunaan media pembelajaran interaktif berbasis Lectora Inspire terdapat perbedaan motivasi belajar antara pembelajaran menggunakan media pembelajaran interaktif rata-rata 6,00 dengan tidak menggunakan media pembelajaran interaktif rata-rata 1,90. Hal serupa diungkapkan oleh Kyong-Jee Kim (2011: 1) bahwa dari 368 pelajar yang disurvei, prediktor terbaik dari peningkatan motivasi selama proses pembelajaran adalah penggunaan media e-learning dalam pembelajaran awal Pembuatan media pembelajaran harus dikemas secara inovatif dan variatif. Jenis media pembelajaran yaitu media visual, media audio, media audiovisual, multimedia dan sebagainya. Arif S. Sadiman. dkk (2014: 17), "penggunaan media pendidikan secara tepat dan bervariasi dapat mengatasi sikap pasif peserta didik". Manfaat penggunaan media pembelajaran selain itu, Daryanto (2016: 56) mengungkapkan manfaat media pembelajaran antara lain adalah: 1) memperjelas pesan agar tidak terlalu verbalistis; 2) mengatasi keterbatasan ruang, waktu, tenaga dan daya indra; 3) menimbulkan gairah belajar, interaksi lebih langsung antara murid dengan sumber belajar; 4) memungkinkan anak belajar mandiri sesuai dengan bakat dan kemampuan visual, auditori dan kinestetiknya; 5) memberi rangsangan yang sama, mempersamakan pengalaman dan menimbulkan persepsi yang sama; 6) Proses pembelajaran mengandung ilmu komponen komunikasi, guru (komunikator), bahan pembelajaran, media 
pembelajaran, siswa (komunikan) dan tujuan pembelajaran.

Media pembelajaran yang interaktif akan membantu siswa untuk aktif dan termotivasi dalam mengikuti proses pembelajaran. Pengembangan media pembelajaran yang interaktif dapat dilakukan dengan berbagai cara. Pemanfaatan fasilitas sekolah yang sudah ada menjadi alternatif penunjang dalam pengembangan media pembelajaran yang dapat digunakan oleh guru. Fasilitas atau sarana prasarana sekolah diwujudkan dengan adanya ruang teori, ruang praktik, perpustakaan, laboratorium komputer, peralatan praktik, media pembelajaran dan sebagainya. Berdasarkan fasilitas yang sudah ada di sekolah, media pembelajaran interaktif dapat dikembangkan dengan berbasis komputer. "Media berbasis komputer adalah penggunaan komputer dalam penyampaian bahan ajar kepada siswa sehingga siswa mampu memberikan umpan balik. Media berbasis komputer bisa berbentuk tutorial, drills and practice, simulasi dan permainan" (Arsyad, 2017: 150). Media interaktif dapat memberikan bantuan kepada guru dalam penyampaian materi, evaluasi serta umpan balik dari siswa. Pembuatan media dengan konten berbasis komputer harus sesuai dengan kurikulum dan mengikuti pedoman yang ditetapkan. Guru harus menemukan formulasi khusus terhadap pembelajaran dan materi yang akan disampaikan bisa dengan mudah diakses oleh siswa dengan menggunakan berbagai perangkat. Salah satu media pembelajaran interaktif yang dapat dikembangkan adalah menggunakan software Lectora Inspire.

Lectora Inspire adalah perangkat lunak Authoring Tool untuk pengembangan konten $e$-learning yang dikembangkan oleh Triviants Corporation. "Pada tahun 2000, Lectora menjadi yang pertama sistem authoring AICC bersertifikat di pasar. Lectora Inspire dapat digunakan untuk menggabungkan flash, merekam video, menggabungkan gambar dan screen capture" (Mas'ud, 2014: 1). Irina\&Liviu (2011: 1-2) yang berjudul Lectora a Complete E-Learning Solution memberikan pendapat bahwa Lectora Inspire menjadi salah satu solusi pembuatan media pembelajaran interaktif lengkap untuk pendidikan dengan sumber daya bawaan pengembangan yang cepat. Keunggulan Lectora Inspire dibandingkan dengan software pengembang media pembelajaran lainnya adalah software ini dibuat dengan konten flash terkemuka, tangkapan layar, perekaman, alat otorisasi yang kuat sehingga memungkinkan untuk membuat video dan konten flash dengan cepat. Lectora Inspire mempunyai berbagai template yang bisa mempermudah guru untuk mengintegrasikan materi dan evaluasi dalam pembelajaran. Pengembangan media pembelajaran interaktif berbasis Lectora Inspire dapat memanfaatkan fasilitas sekolah dengan baik dan menarik perhatian siswa, lingkungan belajar menjadi lebih kondusif, santai dan menyenangkan sehingga dapat membantu siswa dalam memahami materi dan bisa melibatkan siswa dalam proses pembelajaran (Railean Elena, 2013: 68-73). Manfaat penggunaan Lectora Inspire sebagai media pembelajaran interaktif antara lain pengembangan media pembelajaran mudah dilakukan, terdapat fitur penggabungan materi dan evaluasi sehingga mempermudah guru dalam pengoperasiannya, kelengkapan konten 
yang ada di dalam Lectora Inspire menambah kreativitas dalam mengembangkan media pembelajaran yang lebih menarik, akses penggunaan media pembelajaran bisa dilakukan secara offline sehingga pengguna bisa menggunakan secara mandiri dan produk akhir media pembelajaran dapat dioperasikan pada komputer/laptop pengguna tanpa harus mempunyai software Lectora Inspire.

Mata pelajaran akuntansi dasar merupakan mata pelajaran yang wajib tempuh dan tuntas untuk satuan pendidikan SMK Kelas X Semester 1 dan 2. Salah satu kompetensi dasar dalam mata pelajaran akuntansi dasar semester 2 adalah materi jurnal penyesuaian. Berdasarkan wawancara dengan guru mata pelajaran akuntansi dasar Ibu Sumiyati pada bulan Januari 2019, beliau mengatakan bahwa materi jurnal penyesuaian merupakan materi yang dirasa sulit, sehingga guru harus menjelaskan berulang-ulang untuk dapat memberikan pemahaman kepada siswa. Materi jurnal penyesuaian akan lebih mudah dipahami oleh siswa apabila guru menggunakan media pembelajaran interaktif dalam penyampaian materi tersebut.

Berdasarkan observasi terhadap proses pembelajaran yang dilakukan saat observasi awal pada tanggal 11 Januari 2019 di kelas $\mathrm{X}$ Akuntansi dan Keuangan Lembaga 1 SMK Negeri 1 Tempel Tahun Ajaran 2018/2019, ditemukan masalah pada metode mengajar guru di kelas X Akuntansi dan Keuangan Lembaga 1. Guru masih dominan menggunakan media tradisional papan tulis, handout dan lembar kerja siswa pada saat proses pembelajaran. Penggunaan metode mengajar tersebut membuat respon siswa kurang maksimal. Siswa bagian belakang tidak memperhatikan penjelasan guru dan malah asik mengrobrol dengan teman sebangku. Mereka terlihat kurang antusias untuk mengikuti proses pembelajaran. Pemanfaatan fasilitas di sekolah juga kurang maksimal. Guru masih menggunakan metode konvensional padahal dalam ruangan tersebut sudah tersedia LCD Proyektor. Berdasarkan wawancara dengan guru, dalam pembelajaran guru sering menggunakan power point, media papan tulis, buku teks, lembar kerja siswa dan belum menggunakan media pembelajaran yang lebih interaktif. Hal ini dikarenakan terlalu banyaknya beban administrasi guru sehingga mereka tidak mempunyai waktu lagi untuk mengembangkan metode/media pembelajaran yang kreatif. Selain permasalahan tersebut, ditemukan masalah lain yaitu belum adanya pengembangan media pembelajaran berbasis komputer oleh guru yaitu pada materi jurnal penyesuaian. Media pembelajaran interaktif berbasis Lectora Inspire dipilih sebagai media pembelajaran yang tepat untuk SMK Negeri 1 Tempel khususnya pada materi jurnal penyesuaian. Media pembelajaran ini dapat disusun dengan mudah dan memanfaatkan fasilitas komputer yang sudah ada di sekolah. Pembuatan media yang mudah dan desain sesuai dengan keinginan pengembang.

Berdasarkan penelitian terdahulu yang dilakukan oleh Kartika Bunga Nadhya Noor (2018) yang berjudul "Development $O f$ Interactive Learning Media Based On Komputer Using Lectora Inspire Software On Basic Accounting Subject To Improve Student Learning Motivation Of Class X AK 1 In SMK Muhammadiyah 1 Yogyakarta" hasil penelitian menunjukkan bahwa media 
pembelajaran interaktif pada mata pelajaran Akuntansi Dasar dinyatakan Sangat Layak dengan skor rata-rata 4,5 oleh ahli materi, 4,47 oleh ahli media, 4,35 oleh guru akuntansi, dan 4,29 oleh siswa. Motivasi belajar kelompok perlakuan meningkat sebesar $6 \%$ dari $73 \%$ menjadi $79 \%$ sedangkan kelompok kontrol meningkat sebesar $2 \%$ dari $74 \%$ menjadi $76 \%$. Dalam paired sample t-test, X AK 1 memperoleh t empiris -8.889 dengan sig. 0,000 sedangkan $\mathrm{X}$ AK 2 memperoleh $\mathrm{t}$ empiris $-3,456$ dengan sig. 0,000. Hal ini menunjukkan bahwa media pembelajaran yang digunakan di setiap kelas dapat meningkatkan motivasi belajar siswa. Namun pada independent ttest, X AK 1 memperoleh rata-rata 6,00 dan $\mathrm{X}$ AK 2 memperoleh 1,90 dengan sig 0,000 yang menunjukkan bahwa ada perbedaan peningkatan motivasi belajar siswa antara kelompok perlakuan dan kelompok kontrol. Berdasarkan penelitian terdahulu yang lain yang dilakukan oleh Andy Sudarmaji (2015) yang berjudul "Pengembangan Media Pembelajaran Berbasis Aplikasi Lectora Inspire untuk Mata Pelajaran Sistem AC di SMK Negeri 2 Klaten" menunjukkan hasil bahwa penilaian dari ahli materi untuk media pembelajaran yang dibuat mendapatkan rerata skor sebesar 3,8 dalam kategori sangat layak. Hasil penilaian dari ahli media untuk media pembelajaran yang dibuat mendapatkan rerata skor sebesar 3,4 dalam kategori layak. Hasil penilaian dari uji coba produk untuk media pembelajaran yang dibuat mendapatkan rerata skor sebesar 3,0 dalam kategori layak. Hasil penilaian dari uji coba pemakaian untuk media pembelajaran yang dibuat mendapatkan rerata skor sebesar 3,4 dalam kategori layak. Sehingga disimpulkan bahwa dengan merujuk pada penilaian dari ahli materi, ahli media, uji coba produk, dan uji coba pemakaian dapat dinyatakan media pembelajaran sistem AC dengan basis aplikasi Lectora Inspire layak digunakan sebagai media pembelajaran.

Berdasarkan uraian tersebut, maka peneliti melakukan penelitian pengembangan dengan judul "Pengembangan Media Pembelajaran Interaktif Berbasis Lectora Inspire Pada Materi Jurnal Penyesuaian Untuk Siswa Kelas X Akuntansi dan Keuangan Lembaga SMK Negeri 1 Tempel Tahun Ajaran 2018/2019". Pengembangan media pembelajaran interaktif berbasis Lectora Inspire ini diharapkan dapat membantu guru untuk penyampaian materi dalam proses pembelajaran. Tujuan dari penelitian ini adalah: 1) mengembangkan Media Pembelajaran Interaktif Berbasis Lectora Inspire Pada Materi Jurnal Penyesuaian untuk Siswa Kelas X Akuntansi dan Keuangan Lembaga SMK N 1 Tempel; 2) menghasilkan Media Pembelajaran Interaktif Berbasis Lectora Inspire Pada Materi Jurnal Penyesuaian untuk Siswa Kelas X Akuntansi dan Keuangan Lembaga SMK N 1 Tempel yang layak digunakan berdasarkan penilaian ahli materi, ahli media dan praktisi pembelajaran (guru); dan 3) mengetahui penilaian kelayakan Media Pembelajaran Interaktif Berbasis Lectora Inspire Pada Materi Jurnal Penyesuaian untuk Siswa Kelas X Akuntansi dan Keuangan Lembaga SMK N 1 Tempel berdasarkan penilaian siswa.

\section{METODE PENELITIAN}

\section{Jenis Penelitian}

Penelitian ini menggunakan jenis metode penelitian dan pengembangan (Research and Development). Metode 
penelitian dan pengembangan adalah metode penelitian yang digunakan untuk menghasilkan produk tertentu dan menguji kelayakan produk tersebut (Sugiyono, 2015: 297). Penelitian ini menggunakan model ADDIE yang dikembangkan oleh Dick dan Carey meliputi lima tahapan yaitu Analysis, Design, Development, Implementation dan Evaluation yang telah dimodifikasi sehingga menghasilkan sebuah model pengembangan yang lebih sederhana.

\section{Tempat dan Waktu Penelitian}

Penelitian ini akan dilakukan di SMK Negeri 1 Tempel yang beralamat di Jalan Magelang Km 17, Ngebong Margorejo Tempel Sleman DIY. Penelitian dilaksanakan secara bertahap dari bulan Januari-Maret 2019 sesuai dengan pengembangan media pembelajaran.

\section{Subjek dan Objek Penelitian}

Subjek penelitian ini adalah satu orang Ahli Materi, satu orang Ahli Media, satu orang Praktisi pembelajaran dan siswa kelas X Akuntansi dan Keuangan Lembaga 1 yang terdiri dari 30 siswa. Objek penelitian yang akan diteliti adalah kelayakan media pembelajaran interaktif berbasis lectora inspire yang meliputi aspek rekayasa perangkat lunak, aspek desain pembelajaran dan aspek komunikasi visual.

\section{Prosedur Pengembangan}

Prosedur pengembangan Media Pembelajaran Interaktif Berbasis Lectora Inspire ini mengacu pada langkah-langkah adopsi pengembangan model ADDIE dalam penerapannya dengan kebutuhan dari produk dan materi pelajaran yang dikembangkan. "model ADDIE dapat digunakan untuk berbagai bentuk pengembangan seperti model, strategi pembelajaran, metode pembelajaran, media dan bahan ajar" (Endang M, 2012; 183184). Prosedur pengembangan Media Pembelajaran Interaktif Berbasis Lectora Inspire yaitu:

a) Tahap Analisis (Analysis) Tahap ini dilakukan dengan
menganalisis kebutuhan untuk memperoleh informasi dan kebutuhan media pembelajaran yang bisa digunakan di dalam kelas

b) Tahap Desain (Design)

Tahap desain ini peneliti mulai merancang konsep desain media pembelajaran, menyusun materi, soal dan kunci jawaban serta memilih background, gambar, karakter dan backsound

c) Tahap Pengembangan (Development)

Tahap ini peneliti mulai melakukan pembuatan produk media pembelajaran dan melakukan validasi kepada ahli materi, ahli media dan praktisi pembelajaran (guru). Setelah validasi akan dilakukan revisi sesuai saran;

d) Tahap Implementasi (Implementation)

Tahap ini dilakukan dengan melakukan uji coba kelompok kecil dan uji coba lapangan. Uji coba kelompok kecil dilaksanakan di kelas X Akuntansi dan Keuangan Lembaga 3 sebanyak 9 siswa (masing-masing kelompok 3 anak). Uji coba lapangan dilaksanakan di kelas X Akuntansi dan Keuangan Lembaga 1 sebanyak 30 siswa.

e) Tahap Evaluasi (Evaluation)

Tahap ini dilakukan untuk mengukur keberhasilan tujuan 
pengembangan produk media pembelajaran berbasis Lectora Inspire yaitu hasil analisis kelayakan produk akhir

\section{Data, Instrumen dan Teknik Pengumpulan Data}

Data yang digunakan dalam penelitian ini adalah data kualitatif dan data kuantitatif. Data kualitatif adalah data tentang proses pengembangan media pembelajaran berupa kritik dan saran dari validator media. data kuantitatif adalah data pokok dalam penelitian ini berupa penilaian tentang media pembelajaran oleh validator. Instrumen yang digunakan untuk mengumpulkan data dalam penelitian ini adalah menggunakan angket/kuisioner. Penilaian pada angket ini menggunakan skala Likert (skala 5). Alternatif jawaban dari penilaian angket tersebut adalah SB $($ Sangat Baik $)=5, \mathrm{~B}($ Baik $)=4, \mathrm{C}($ Cukup $)$ $=3, \mathrm{~K}$ (Kurang Baik) = 2, dan SK (Sangat Kurang Baik) $=1$ (Sugiyono, 2015: 93). Angket ini tidak memiliki pertanyaan negatif karena untuk menilai kelayakan media pembelajaran.

\section{Teknik Analisis Data}

Data yang diperoleh akan dianalisis untuk mengetahui penilaian dan pendapat dari produk yang dihasilkan.

a. Mengubah data penilaian kualitatif menjadi kuantitatif dengan ketentuan:

Tabel 1. Kriteria Penskoran
\begin{tabular}{|l|l|}
\hline Kriteria & Skor \\
\hline Sangat Baik & 5 \\
\hline Baik & 4 \\
\hline Cukup & 3 \\
\hline Kurang Baik & 2 \\
\hline $\begin{array}{l}\text { Sangat Kurang } \\
\text { Baik }\end{array}$ & 1 \\
\hline
\end{tabular}

Sumber: Sugiyono (2015: 93) b. Menghitung nilai rerata skor tiap indikator dengan rumus:

$$
\bar{X}=\frac{\Sigma X}{N}
$$

Keterangan:

$$
X \quad=\text { skor rata-rata }
$$

$\sum x=$ jumlah skor

$\mathrm{N}=$ jumlah subjek uji coba

(Eko Putro W, 2017: 237)

c. Interpretasi secara kualitatif nilai ratarata tiap aspek dengan kriteria sebagai berikut:

Tabel 2. Pedoman Konversi Nilai

\begin{tabular}{|c|c|c|}
\hline Skor & Rumus & Klasifikasi \\
\hline 5 & $\mathrm{X}>4,20$ & $\begin{array}{c}\text { Sangat } \\
\text { Layak }\end{array}$ \\
\hline 4 & $3,40<\mathrm{X} \leq 4,20$ & Layak \\
\hline 3 & $2,60<\mathrm{X} \leq 3,40$ & Cukup \\
\hline 2 & $1,80<\mathrm{X} \leq 2,60$ & Tidak Layak \\
\hline 1 & $1<\mathrm{X} \leq 1,80$ & $\begin{array}{c}\text { Sangat } \\
\text { Tidak Layak }\end{array}$ \\
\hline
\end{tabular}

Sumber: Eko Putro Widoyoko (2018: 112)

Berdasarkan tabel konversi diatas diperoleh standar kelayakan media pembelajaran interaktif berbasis Lectora Inspire dari setiap aspek sebagai berikut:

a. Media pembelajaran interaktif berbasis Lectora Inspire dinyatakan Sangat Layak apabila rata-rata skor yang diperoleh adalah pada rentang 4,21-5,00.

b. Media pembelajaran interaktif berbasis Lectora Inspire dinyatakan Layak apabila ratarata skor yang diperoleh adalah pada rentang 3,40-4,20.

c. Media pembelajaran interaktif berbasis Lectora Inspire dinyatakan Cukup apabila rata- 
rata skor yang diperoleh pada rentang 2,61-3,40.

d. Media pembelajaran interaktif berbasis Lectora Inspire dinyatakan Tidak Layak apabila rata-rata skor yang diperoleh pada rentang $1,81-2,60$.

e. Media pembelajaran interaktif berbasis Lectora Inspire dinyatakan Sangat Tidak Layak apabila rata-rata skor yang diperoleh pada rentang $1-1,80$.

\section{HASIL PENELITIAN DAN PEMBAHASAN

Hasil Pengembangan Media \\ Pembelajaran Interaktif Berbasis Lectora Inspire.}

Pengembangan media pembelajaran berbasis Lectora Inspire ini merupakan adaptasi dan modifikasi dari langkah penelitian dan pengembangan model ADDIE yaitu: 1) Analisis (analysis): 2) Desain (design); 3) Pengembangan (development); 4) Implementasi (implementation); 5) Evaluasi (evaluation).

a) Tahap Analisis (Analysis)

Pada tahap analisis, peneliti melakukan observasi dan wawancara di kelas X Akuntansi dan Keuangan Lembaga 1 SMK Negeri 1 Tempel. Observasi dilakukan pada tanggal 11 Januari 2019. Jumlah siswa yang hadir adalah 32 siswa. Berdasarkan wawancara dengan guru Mata Pelajaran Akuntansi Dasar, Ibu Sumiyati, S.Pd. mengenai pentingnya penggunaan media pembelajaran, selama ini guru hanya menggunakan media power point sederhana, buku paket dan soal latihan. Kegiatan pembelajaran yang cenderung monoton mengakibatkan siswa bosan. Hal ini ditandai dengan banyaknya siswa yang duduk dibagian belakang tidak memperhatikan penjelasan guru dan asik mengobrol dengan teman sebangku. Mereka terlihat kurang antusias mengikuti proses pembelajaran. Pemanfaatan fasilitas seharusnya digunakan semaksimal mungkin, contohnya penggunaan LCD dan proyektor sebagai penunjang penyampaian materi. Tetapi dalam proses pembelajaran tersebut penggunaan fasilitas belum maksimal. Berdasarkan analisis tersebut peneliti bermaksud untuk mengembangkan media pembelajaran interaktif berbasis Lectora Inspire. Media pembelajaran ini dapat digunakan oleh siswa maupun guru dalam proses pembelajaran.

b) Tahap Desain (Design)

Pada tahap desain, peneliti merancang konsep desain pembelajaran secara keseluruhan (storyboard), penyusunan materi, soal dan kunci jawaban, serta pemilihan background, gambar, karakter dan backsound. Konsep dari media pembelajaran ini adalah berupa modul interaktif yang berisi materi, contoh soal dan evaluasi. Materi yang dimuat dalam media ini adalah kompetensi dasar menyusun jurnal penyesuaian.

c) Tahap Pengembangan (Development)

Pada tahap pengembangan, peneliti membuat media pembelajaran dengan software Lectora Inspire. Seluruh komponen yang telah dipersiapkan di storyboard kemudian dirangkai menjadi satu kesatuan media pembelajaran berbasis Lectora Inspire. Tampilan dari media ini terdiri dari petunjuk, kompetensi, materi, evaluasi, pustaka dan profil. Media pembelajaran ini dilakukan dua kali validasi. Validasi I dilakukan oleh ahli materi dan ahli media dari dosen Jurusan Pendidikan Akuntansi Fakultas Ekonomi Universitas Negeri Yogyakarta. 
Peneliti melakukan revisi I atas saran dan pendapat dari ahli materi dan ahli media. Validasi II dilakukan oleh praktisi pembelajaran (guru) yaitu guru Akuntansi Dasar SMK Negeri 1 Tempel dan selanjutnya dilakukan revisi II. Adapun produk akhir media pembelajaran yang siap diimplementasikan adalah sebagai berikut:

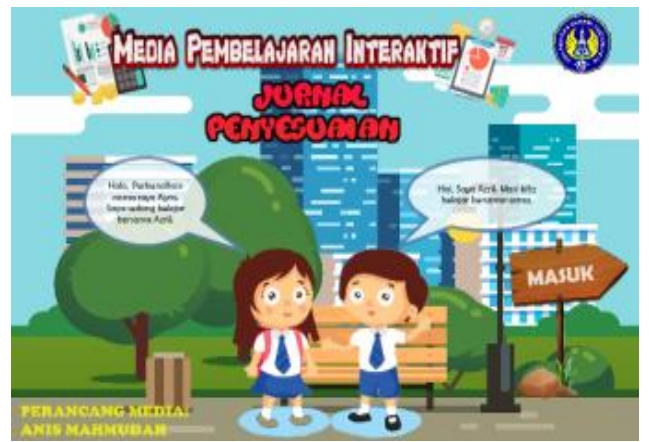

Gambar 1. Tampilan Awal Media
Tahap implementasi dilakukan uji coba kelompok kecil dan uji coba lapangan. Hasil uji coba kelompok kecil tersebut tidak ada revisi terkait media pembelajaran yang dikembangkan sehingga dilanjutkan ke uji coba lapangan. Dalam tahap uji coba ini siswa diberikan laptop yang sudah terinstall media pembelajaran interaktif berbasis Lectora Inspire. Pada akhir pelajaran, siswa diberikan angket untuk memberikan respon dan penilaian terhadap media pembelajaran yang dikembangkan.

e) Tahap Evaluasi (Evaluation)

Tahap evaluasi dilakukan dengan membandingkan hasil penilaian dalam setiap tahapan. Berikut ini rekapitulasi hasil penilaian media pembelajaran dari seuruh tahapan:

d) Tahap Implementasi (Implementation)

Tabel 3. Kelayakan Media Setiap Tahapan

\begin{tabular}{|c|l|c|c|c|}
\hline No. & \multicolumn{1}{|c|}{ Tahapan Penelitian } & Jumlah Skor & $\begin{array}{c}\text { Rata-rata } \\
\text { Skor }\end{array}$ & Kategori \\
\hline 1 & Ahli Materi & 82 & 4,53 & Sangat Layak \\
\hline 2 & Ahli Media & 112 & 4,48 & Sangat Layak \\
\hline 3 & Praktisi pembelajaran & 91 & 4,60 & Sangat Layak \\
\hline 4 & Ujicoba Kelompok Kecil & 801 & 4,45 & Sangat Layak \\
\hline 5 & Ujicoba Lapangan & 2546 & 4,24 & Sangat Layak \\
\hline \multicolumn{2}{|c|}{ Rata-rata keseluruhan } & 726,4 & 4,46 & Sangat Layak \\
\hline
\end{tabular}

kelayakannya oleh satu orang ahli materi

Berdasarkan tabel 3 di atas kelayakan media pembelajaran dari seluruh tahapan mendapatkan skor 4,46 yang menyatakan bahwa media pembelajaran interaktif berbasis Lectora Inspire tersebut sangat layak digunakan sebagai media pembelajaran.

\section{Hasil Penilaian Kelayakan Media Pembelajaran Interaktif Berbasis Lectora Inspire.} Media pembelajaran interaktif Berbasis Lectora Inspire dinilai (Dosen Jurusan Pendidikan Akuntansi FE UNY) dengan memperoleh hasil skor ratarata 4,53 yang masuk dalam kategori "Sangat Layak". Selanjutnya dinilai oleh satu orang ahli media (Dosen Jurusan Pendidikan Akuntansi FE UNY) dengan memperoleh hasil rata-rata keseluruhan 4,48 yang masuk dalam kategori "Sangat Layak" dan satu orang praktisi pembelajaran (guru akuntansi SMK Negeri 1 Tempel) dengan memperoleh hasil ratarata keseluruhan 4,60 yang masuk dalam kategori "Sangat Layak". Hasil rekapitulasi 
penilaian oleh seluruh ahli adalah sebagai berikut:

Tabel 4. Rekapitulasi Penilaian Ahli

\begin{tabular}{|c|l|c|c|}
\hline No. & $\begin{array}{c}\text { Tahapan } \\
\text { Penilaian }\end{array}$ & $\begin{array}{c}\text { Rata- } \\
\text { Rata }\end{array}$ & Kategori \\
\hline 1 & Ahli Materi & 4,53 & $\begin{array}{c}\text { Sangat } \\
\text { Layak }\end{array}$ \\
\hline 2 & Ahli Media & 4,48 & $\begin{array}{l}\text { Sangat } \\
\text { Layak }\end{array}$ \\
\hline 3 & $\begin{array}{l}\text { Praktisi } \\
\text { Pembelajaran }\end{array}$ & 4,60 & $\begin{array}{l}\text { Sangat } \\
\text { Layak }\end{array}$ \\
\hline $\begin{array}{l}\text { Rata-rata } \\
\text { keseluruhan }\end{array}$ & 4,54 & $\begin{array}{l}\text { Sangat } \\
\text { Layak }\end{array}$ \\
\hline
\end{tabular}

Berdasarkan penilaian seluruh ahli diperoleh skor rata-rata 4,54 yang masuk dalam rentang $\mathrm{X}>4,21$ sehingga mendapatkan kategori "Sangat Layak".

\section{Hasil Penilaian Siswa terhadap Implementasi Media Pembelajaran Interaktif Berbasis Lectora Inspire.}

Penilaian siswa terhadap media pembelajaran berbasis lectora inspire dilakukan pada tahap implementasi. Siswa menilai produk media yang telah dikembangkan oleh peneliti melalui angket. Penilaian dilakukan dengan dua tahap yaitu uji coba kelompok kecil dan uji coba lapangan.

Tahap pertama yaitu uji coba kelompok kecil yang melibatkan 9 siswa (masing-masing 3 siswa) kelas X Akuntansi dan Keuangan Lembaga 3. Hasil rekapitulasi uji coba kelompok kecil oleh siswa adalah sebagai berikut:

Tabel 5. Hasil Uji Coba Kelompok Kecil

\begin{tabular}{|c|l|c|c|c|}
\hline No. & \multicolumn{1}{|c|}{ Aspek } & Jumlah Skor & $\begin{array}{c}\text { Rata- } \\
\text { Rata }\end{array}$ & Kategori \\
\hline 1 & Aspek Rekayasa Perangkat Lunak & 244 & 4,52 & Sangat Layak \\
\hline 2 & Aspek Desain Pembelajaran & 272 & 4,32 & Sangat Layak \\
\hline 3 & Aspek Komunikasi Visual & 285 & 4,52 & Sangat Layak \\
\hline \multicolumn{2}{|c|}{ Rata-rata keseluruhan } & 4,45 & Sangat Layak \\
\hline
\end{tabular}

Berdasarkan tabel di atas, secara keseluruhan hasil uji coba kelompok kecil oleh siswa berdasarkan aspek rekayasa perangkat lunak, aspek desain pembelajaran dan aspek komunikasi visual diperoleh rata-rata 4,45 dan termasuk dalam kategori "Sangat Layak" digunakan sebagai media pembelajaran. Pada tahap uji coba kelompok kecil tidak ditemukan revisi untuk media pembelajaran yang dikembangkan oleh peneliti sehingga bisa dilanjutkan ke tahap uji coba lapangan. Tahap uji coba lapangan melibatkan 30 siswa dari kelas $\mathrm{X}$ Akuntansi dan Keuangan Lembaga 1. Hasil rekapitulasi dari uji coba lapangan adalah sebagai berikut: 
Tabel 6. Hasil Uji Coba Lapangan

\begin{tabular}{|c|l|c|c|c|}
\hline No. & \multicolumn{1}{|c|}{ Aspek } & Jumlah Skor & $\begin{array}{c}\text { Rata- } \\
\text { Rata }\end{array}$ & Kategori \\
\hline 1 & Aspek Rekayasa Perangkat Lunak & 760 & 4,22 & Sangat Layak \\
\hline 2 & Aspek Desain Pembelajaran & 886 & 4,22 & Sangat Layak \\
\hline 3 & Aspek Komunikasi Visual & 900 & 4,29 & Sangat Layak \\
\hline \multicolumn{2}{|c|}{ Rata-rata keseluruhan } & 4,24 & Sangat Layak \\
\hline
\end{tabular}

Berdasarkan tabel di atas, secara keseluruhan hasil uji coba lapangan oleh siswa berdasarkan aspek rekayasa perangkat lunak, aspek desain pembelajaran dan aspek komunikasi visual diperoleh ratarata 4,24 dan termasuk dalam kategori "Sangat Layak" digunakan sebagai media pembelajaran.

\section{Pembahasan}

Penelitian yang telah dilakukan membuktikan bahwa pengembangan media pembelajaran interaktif berbasis lectora inspire sangat layak digunakan sebagai media pembelajaran oleh siswa. Hal ini sejalan dengan penelitian yang dilakukan oleh Kartika Bunga Nadhya Noor (2018) tentang Development of Interactive Learning Media Based on Komputer Using Lectora Inspire Software on Basic Accounting Subject to Improve Student Learning Motivation of Class X AK 1 in SMK Muhammadiyah 1 Yogyakarta, Andy Sudarmaji (2015) tentang Pengembangan Media Pembelajaran Berbasis Aplikasi Lectora Inspire untuk Mata Pelajaran Sistem AC di SMK Negeri 1 Klaten.

Prosedur penelitian dan pengembangan pada penelitian ini mengadaptasi dari rangkuman Instructional Design dengan pendekatan ADDIE Robert Maribe Branch (2009) dalam Sugiyono (2017: 38-39) yang terdiri dari lima tahap yaitu 1) Analysis, 2) Design, 3) Development, 4) Implementation dan 5) Evaluation.

Media Pembelajaran Interaktif Berbasis Lectora Inspire melalui tahap penilaian kelayakan yang dilakukan oleh satu orang ahli materi (Rr. Indah Mustikawati, S.E., M.Si., Ak., CA.,), satu orang ahli media
(Rizqi Ilyasa Aghni, M.Pd.) dan satu orang praktisi pembelajaran (Sumiyati, S.Pd.). Berdasarkan rekapitulasi penilaian keseluruhan ahli pada tabel 15 diperoleh skor rata-rata keseluruhan sebesar 4,53 yang terletak pada rentang $X>4,20$ sehingga mendapatkan kategori "Sangat Layak". Hasil penilaian tersebut menunjukkan bahwa Media Pembelajaran Interaktif Berbasis Lectora Inspire sangat layak untuk digunakan sebagai media pembelajaran di SMK.

Penilaian siswa terhadap media yang dikembangkan dilakukan pada tahap implementasi. Tahap implementasi ini sangat penting karena siswa merupakan sasaran uji coba produk yang dikembangkan. Penilaian siswa dilakukan dengan dua tahap yaitu uji coba kelompok kecil dan Uji Coba Lapangan. Uji coba kelompok kecil melibatkan 9 siswa dari kelas X Akuntansi dan Keuangan Lembaga 3. Uji Coba Lapangan melibatkan 30 siswa dari kelas X Akuntansi dan Keuangan Lembaga 1.

Berdasarkan hasil rekapitulasi penilaian uji coba kelompok kecil (tabel 5) diperoleh nilai rata-rata keseluruhan 4,45. Rata-rata keseluruhan $(\mathrm{X})$ menunjukkan pada angka 4,45 yang terletak pada rentang $X>4,20$ dengan kategori "Sangat Layak", artinya uji coba kelompok kecil Media Pembelajaran Interaktif Berbasis Lectora Inspire sudah baik memenuhi kebutuhan siswa, penggunaan bahasa yang jelas membuat siswa tertarik untuk mencoba mengoperasikan dan memenuhi syarat Uji Coba Lapangan.

Uji Coba Lapangan diperoleh nilai ratarata 4,24. Rata-rata keseluruhan (X) 
menunjukkan pada angka 4,24 yang terletak pada rentang $X>4,20$ yaitu termasuk dalam kategori "Sangat Layak", artinya Media Pembelajaran Interaktif Berbasis Lectora Inspire yang dikembangkan memiliki kriteria yang sangat layak sebagai media pembelajaran yang dapat digunakan siswa dalam proses pembelajaran.

\section{SIMPULAN DAN SARAN}

\section{Simpulan}

Berdasarkan hasil penelitian dan pembahasan maka dapat diambil kesimpulan sebagai berikut:

a. Pengembangan Media Pembelajaran Interaktif Berbasis Lectora Inspire pada materi Jurnal Penyesuaian menggunakan model pengembangan ADDIE. Tahap analisis merupakan tahap awal untuk analisis kebutuhan siswa dan analisis materi yang untuk media pembelajaran yang akan dikembangkan. Tahap desain terdiri dari perancangan konsep desain pembelajaran, pembuatan materi, soal dan kunci jawaban, serta pemilihan background, gambar, karakter dan backsound. Tahap pengembangan meliputi pembuatan media pembelajaran, penilaian oleh ahli materi, ahli media, dan praktisi pembelajaran. Media hasil revisi dari saran ahli, maka Media Pembelajaran Interaktif Berbasis Lectora Inspire pada materi jurnal penyesuaian siap untuk diimplementasikan. Tahap implementasi terdiri dari uji coba kelompok kecil (9 siswa) dan uji coba lapangan (30 siswa). Tahap evaluasi dilakukan dengan membandingkan hasil tahapan uji coba dan merekapitulasi hasil penilaian dari ahli materi, ahli media, praktisi pembelajaran dan siswa.

b. Penilaian kelayakan Media Pembelajaran Interaktif Berbasis Lectora Inspire pada materi Jurnal Penyesuaian berdasarkan Ahli Materi diperoleh nilai rata-rata seluruh aspek sebesar 4,53 yang termasuk dalam kategori "Sangat Layak" digunakan sebagai media pembelajaran Akuntansi, berdasarkan Ahli Media diperoleh nilai rata-rata seluruh aspek sebesar 4,48 yang termasuk dalam kategori "Sangat Layak" digunakan sebagai media pembelajaran, berdasarkan Praktisi pembelajaran (guru) diperoleh rata-rata seluruh aspek sebesar 4,60 yang termasuk dalam kategori "Sangat Layak" digunakan sebagai media pembelajaran Akuntansi.

c. Penilaian siswa terhadap Media Pembelajaran Interaktif Berbasis Lectora Inspire pada materi Jurnal Penyesuaian pada uji coba kelompok kecil diperoleh nilai rata-rata seluruh aspek sebesar 4,45 yang termasuk dalam kategori "Sangat Layak" dan penilaian pada Uji Coba Lapangan diperoleh nilai rata-rata seluruh aspek sebesar 4,24 yang termasuk dalam kategori "Sangat Layak". Berdasarkan penilaian tersebut Media Pembelajaran Interaktif Berbasis Lectora Inspire sangat layak digunakan sebagai media pembelajaran siswa SMK.

\section{Saran}

Berdasarkan kualitas produk yang dikembangkan, kelemahan dan keterbatasan penelitian yang telah dibahas sebelumnya, peneliti memberikan saran pemanfaatan dan pengembangan media lebih lanjut sebagai berikut:

a. Pengembangan media dapat mengikuti tahapan model ADDIE sampai pada tahap evaluasi yang menilai efektivitas penggunaan media sehingga penelitian 
pengembangan dapat dilakukan secara maksimal.

b. Media Pembelajaran Interaktif Berbasis Lectora Inspire perlu dikembangkan dari segi materi agar bisa meluas dan tidak hanya sekedar pada materi jurnal penyesuaian.

c. Media pembelajaran interaktif berbasis Lectora Inspire perlu dikembangkan dengan output yang bisa diterapkan di smartphone sehingga siswa lebih mudah untuk bisa menggunakan belajar mandiri.

\section{DAFTAR PUSTAKA}

Afifah, Nurul. (2015). Problematika Pendidikan di Indonesia. Elementary, $1,41-47$.

Al-Haryono Jusup. (2011). Dasar-Dasar Akuntansi Jilid I. Yogyakarta: STIE YKPN.

Arief S Sadiman. (2015). Media Pendidikan Pengertian, Pengembangan, dan pemanfaatannya. Jakarta: PT Raja Grafindo Persada.

Arsyad, Azhar. (2017). Media Pembelajaran. Jakarta: Rajawali Pers.

Branch, Robert M. (2009). Instructional Design: The ADDIE Approach. New York: Springer.

Daryanto. (2010). Media Pembelajaran. Yogyakarta: Gava Media.

Dewi, Norma., Primadewi, A., \& Iman Sad, Muis. (2017). Media Pembelajaran Interaktif Lectora Inspire Sebagai Inovasi Pembelajaran. Warta LPM, 20, 9-16.
Dimyati \& Mudjiono. (2015) Belajar \& Pembelajaran. Jakarta: PT Rineka Cipta.

Elena, Railena. (2013). An Overview of Textbooks as Open Educational Resources. International Journal of Komputer Science Research and Application, 03, 68-73.

Ionita, L. \& Ionita, Irina. (2011). Lectora-a Complete e-Learning Solution. Makalah disajikan dalam The $6^{\text {th }}$ International Conference on Virtual Learning ICVL.

Jee Kim, Kyong. \& Frick W, Theodore. (2011). Changes In Student Motivation During Online Learning. Journal Education Computing Research, 44(1), 1-23.

Kartika Bunga Nadhya Noor. (2018). "Development Of Interactive Learning Media Based On Komputer Using Lectora Inspire Software On Basic Accounting Subject To Improve Student Learning Motivation Of Class $\mathrm{X}$ AK 1 In SMK Muhammadiyah 1 Yogyakarta. Skripsi. Universitas Negeri Yogyakarta.

Mas'ud, Muhammad. (2014). Membuat Multimedia Pembelajaran dengan Lectora. Yogyakarta: Pustaka Shonif.

Melani, A. (25 Januari 2018). Jack Ma: Ubah Pendidikan agar Bersaing dengan Robot. Diambil pada tangal 15 Januari 2019 dari https://www.liputan6.com/bisnis/read/3 238241/jack-ma-ubah-pendidikan-agarbersaing-dengan-robot

Mulyatiningsih, Endang. (2012). Metode Penelitian Terapan Bidang Pendidikan. Bandung: Alfabeta. 
Sudjana Nana, \& Rivai. (2017). Media Pengajaran. Bandung:PT Sinar Baru Algesindo.

Sanjaya, Wina. (2013). Strategi Pembelajaran. Jakarta: Kencana.

Sugiyono. (2015). Metode Penelitian Kuantitatif, Kualitatif, dan $R \& D$. Bandung: Alfabeta.

(2015). Statistika untuk Penelitian. Bandung: Alfabeta.
(2017). Metode Penelitian dan Pengembangan. Bandung: Alfabeta

Suryani, N., Setiawan, A., \& Putria, A. (2018). Media Pembelajaran Inovatif dan Pengembangannya. Bandung: PT Remaja Rosdakarya

Widoyoko, E.P. (2017). Evaluasi Program Pembelajaran. Yogyakarta: Pustaka Pelajar.

Widoyoko, E.P. (2018). Teknik Penyusunan Instrumen Penelitian. Yogyakarta: Pustaka Pelajar. 